ITEJ Juli-2019, Volume 4 Nomor 1 Page 26 - 38

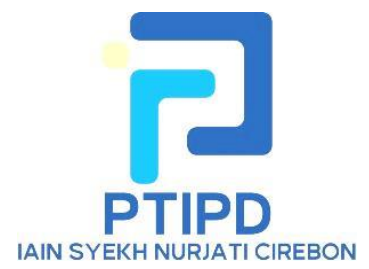

ITEJ

Information Technology Engineering Journals eISSN : $\underline{2548-2157}$

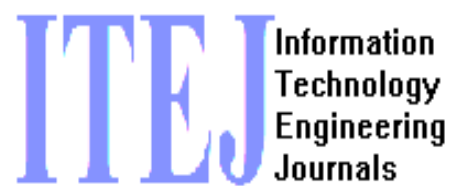

Url : https://syekhnurjati.ac.id/journal/index.php/itej

Email : itej@syekhnurjati.ac.id

\title{
A Survey of Models, Technologies and Trends in Decision Making with Internet of Things
}

\author{
You Ari Faeni \\ Sekolah Teknik Elektro dan Informatika \\ Institut Teknologi Bandung \\ Bandung, Indonesia \\ you@students.itb.ac.id
}

\begin{abstract}
The development of IoT (internet of things) technology encourages increased use of smart devices and their supporting applications. The use of smart devices and applications that are growing rapidly and large will certainly produce large amounts of data and information. The next challenge is how to use the data and information generated to help people solve various problems that exist and improve the quality of human life. Data is analyzed into information, knowledge and in the end it will be used to make decisions. With all the features offered by IoT, decision making is expected to be easier and more precise, according to the expected goals. This paper will discuss the IoT architecture and decision-making framework with IoT. Furthermore, it provides an overview of the models, technology and development of the decision making process with IoT based on previously published papers (journals and conferences). The main purpose of making this paper is to provide insights for researchers about decision making with IoT.
\end{abstract}

Keywords-decision making, IoT, data analytics model, tren IoT, IoT architecture, decision making with IoT model

\section{INTRODUCTION}

Teknologi Komunikasi dan Internet Of Things(IoT) yang terus berkembang, menjadi sebuah enabler bagi pengguna dalam menggunakan smart devices untuk kegiatan sehari - hari baik untuk bisnis atau untuk mendukung kenyamanan kehidupan. IoT merupakan teknologi dimana alat (things) yang berbeda saling berkomukiasi melalui intenet. Alat bisa direpresentasikan sebagai benda atau apapun yang digunakan seperti kendaraan, bangunan, bahkan alat rumah tangga sekalipun.

IoT memunculkan paradigm baru tentang cyber physical system, dimana jutaan smart object mengumpulkan, menganalisis dan dapat saling bertukar infomasi secara luas. Penggunaan data dan informasi yang dikumpulkan pun beragam, untuk analisis masalah, prediksi keadaan yang akan datang, membantu dalam mengambil keputusan, dan lain - lain.

IoT sebagai pembantu dalam pengambilan keputusan memiliki peran dalam pengumpulan, analisis dan pertukaran informasi. Informasi yang didapatkan dari sensor/device IoT kemudian diproses lebih lanjut menggunakan berbagai algoritma yang sesuai dengan kebutuhan pengguna. Selanjutnya, hasil dari analisis data dapat digunakan untuk melakukan proses pengambilan keputusan.

\section{A. Decision Making}

Pengambilan keputusan (decision making) merupakan sebuah proses kognitif yang dihasilkan dari pemilihan suatu solusi/keputusa dari beberapa alternative kemungkinan yang ada. Setiap proses 
pengambilan keputusan pasti menghasilkan pilihan final yang optimal sesuai dengan permintaan pengguna.

Berbagai peneliti telah merumuskan langkah-langkah preskriptif dalam melakukan pengambilan keputusan antara lain:

- GOFFER (Goal Clarification, Option generation, Facts-finding, Consideration of Effects dan Review and Implementation) [1] oleh psychologist Leon Mann pada tahun 1980

- DECIDE(define the Problem, Enumerate all criteria, Collect all alternatives, Identify best alternatives, Develop and implement plant of action) [2] oleh Kristina Guo pada tahun 2008

Perilaku manusia telah menjadi subjek penelitian dalam decision-making[2]. Ada beberapa perspektif yang diteliti antara lain:

- Cognitive : proses pengambilan keputusan dianggan sebagai proses berkelanjutan yang terintegrasi dalam interaksi manusia dengan lingkungan

- Psychological : pengambilan keputusan secara individu dalam konteks serangkaian kebutuhan, preferensi dan nilai-nilai yang dimiliki dari individu

- Normative: analisis pengambilan keputusan yang berkaitan dengan logika dalam pengambilan keputusan, rasionalitas, komunikasi dan tujuan pemilihan keputusan.

Berbagai teknik dalam pengambilan keputusan tela ada bahkan semenjak manusia mulai melakukan interaksi dengan sesamanya. Secara global teknis pengambilan keputusan dibagi dalam 2 kategori yaitu pengambilan keputusan dalam kelompok(group decision-making) dan pengambilan keputusan secara individu (individual decision-making).

Beberapa teknik pengambilan keputusan[2] antara lain:

- Consensus / musyawarah : teknik pengambilan keputusan dimana tidak ad yang menang atau pun yang kalah. Keputusan diambil berdasarkan kesepakatan bersama(group)

- Voting : teknik pengambilan keputusan dimana pilihan yang memiliki pendukung terbanyak yang menjadi keputusan final/akhir (group)

- Decision balanced sheet : teknik pengambilan keputusan dengan menulis semua alternative keputusan yang ada(pro/kontra, untung/rugi)

- Expected value optimization : teknik pengambilan keputusan dengan memilih pilihan dengan peluang paling besar dengan mempertimbangkan resiko dan biaya yang akan muncul,

- Satisficing : teknik pengambilan keputusan dimana pilihan yang digunakan adalah alternative sesuai pertama yang ditemukan. Tanpa memperhatikan resiko dan biaya yang ditimbulkan.

- Decision engineering/decision support system : teknik pengambilan keputusan menggunakan teknologi yang ada memanfaatkan big data, machine learning, expert sytem dll (group/individu)

B. IoT

Istilah IoT pertama kali dikemukakan oleh Kevin Aston pada tahun 1999. Pada saat itu Kevin menyampaikan Radio Frequency Identification(RFID) merupakan teknologi utama dan sangat esensial bagi IoT. RFID terdiri dari RFID tags dan RFID reader yang memiliki harga murah. Teknologi ini memungkinkan komputer untuk mengelola semua hal(things) secara lebih mudah dan murah.

Secara umum IoT dapat didefinisikan sebagai jaringan kompleks, adaptif dan dapat mengkonfigurasi dirinya sendiri yang memungkinkan beberapa objek/benda/things seperti RFID tag, sensor, actuator, dan smartphone menggunakan skema addressing yang unik, untuk berinteraksi dan bekerja sama satu sama lain dalam mencapai tujuan tententu.

Beberapa fitur utama IoT[3] antara lain:

- Sensing Capability: things dalam konteks IoT dapat melkukan proses sensing 
- Addressing modes: IoT support dengan berbagai jenis transmisi seperti any-cast, broadcast, multicast dll

- High reliability : Iot menjamin konektivitas dan transmisi yang handal dengan berbagai solusi

- Heterogeneity: support berbagai jenis network seperti wireless, wired, cellular, dll

- Self-* Capabilities: (i) konfigurasi mudah, (ii) self-organization, self-adaptation dalan berbagai scenario, (iii)self-processing dari sejumlah data besar yang ditukarkan.

- Secure Environment : IoT support dengan segala jenis keamanan, otentikasi, privasi, integritas data dll

Untuk mesuport semua fitur diatas berbagai jenis asitektur IOT diusulkan. Secara umum, arsitektur IoT[3] dapat digambarkan seperti gambar dibawah ini :

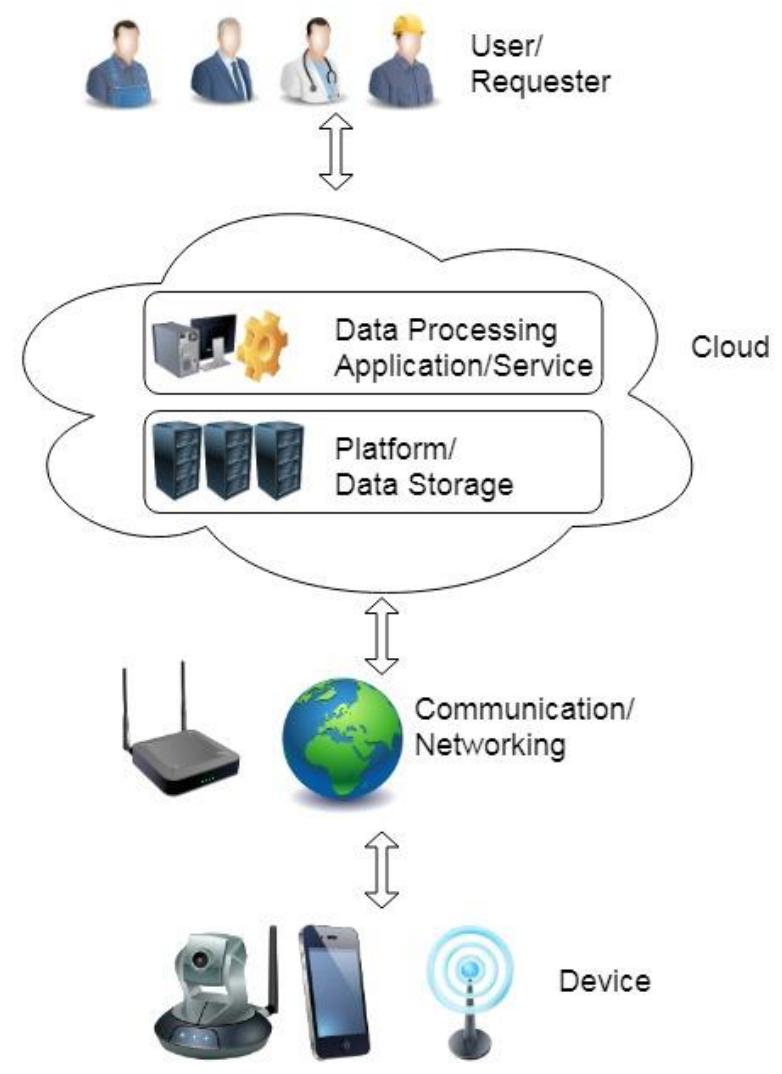

Gambar 1. Arsitektur IoT

- Devices : layer ini berisi alat/things seperti RFID, semsor,dan smart device yang memiliki kemampuan dan resource storage yang terbatas yang fungsinya mengumpulkan data dari suatu entitas misalnya, suhu, kelembaban udara, gerakan dll. Fungsi lain dari device adalah untuk melakukan koneksi dengan internet gateway dalam agrgasi data dan pengiriman data

- Networking dan Communication : layer ini terdiri dari data communication dan infrastruktur network seperti Wireless, MQTT, cellular dll yang berguna untuk menghubungkan device dengan layer berikutnya pada cloud.

- Platform dan Penyimpanan Data: layer ini berisi hardware dan platform dalam data center atau service pada cloud yang bertujuan untuk melakukan akses data atau ruang penyimpanan data

- Data Processing Application/Service : layer ini berisi aplikasi untuk melakukan pemrosesan data yang dikumpulkan device IoT 


\section{Decision Making Dengan IoT}

Pengambilan keputusan dengan IoT melibatkan proses inferensi yang berkelanjutan, pengolahan data hasil dari device IoT dan Interpretasi dari informasi yang dihasilkan. Dalam aplikasi IoT pengambilan keputusan dibutuhkan misalnya pemilihin rute tercepat, penanganan pasien yang harus segera dioperasi, penggantian komponen pada suatu kendaraan bahkan penambahan pupuk atau pestisida pada tanaman bisa diputuskan dengan bantuan teknologi IoT.

Secara garis besar tata cara pengambilan keputusan dengan IoT dapat digambarkan dengan gambar berikut:

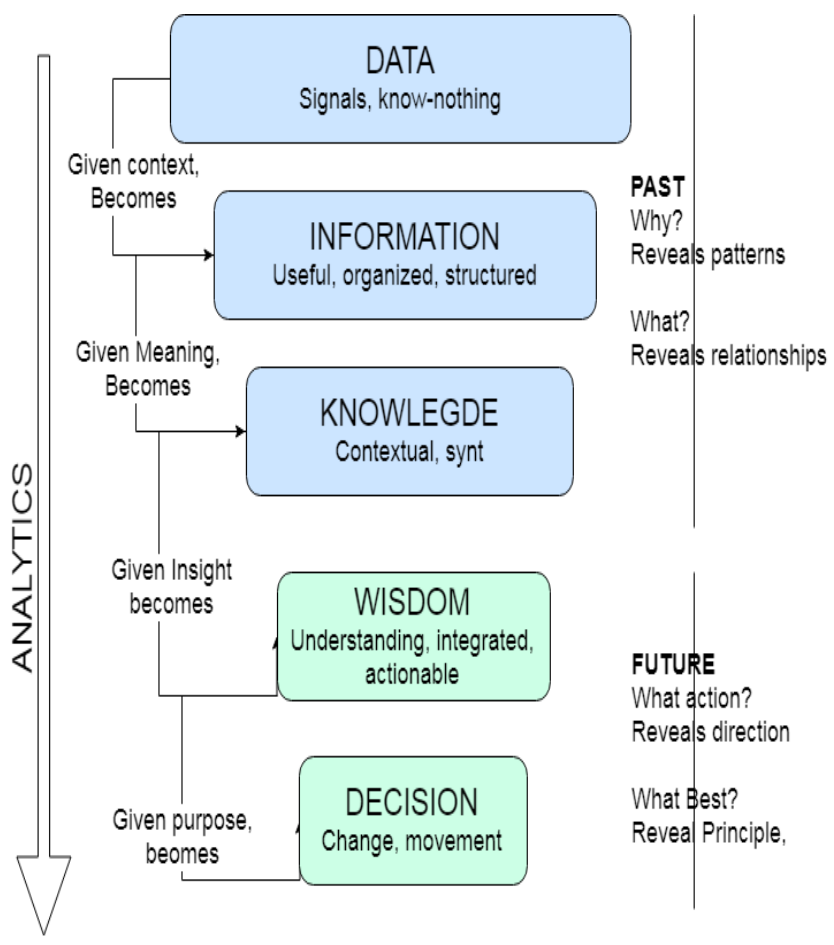

Gambar 2. Framework Decision Making dengan IoT

Dari gambar diatas dapat kita lihat bagaiman proses pengambilan keputusan dengan IoT.

- Data yang dikirim dari alat/things masih berupa angka-angka yang belum memiliki makna apapun.

- Data yang diberi konteks data akan berubah menjadi informasi yang sudah memiliki kegunaan, tersruktur dan mengandur maksud tertentu

- Informasi selanjutnya diberi makna sehingga menjadi sebuah knowledge yang telah memiliki maka tertentu dalam sebuah konteks

- Data, Informasi dan Knowlegde biasanya digunakan untuk menganalisis atau menggambarkan keadaan pada masa lalu untuk mengetahui pola dan hubungan antara suatu konteks dengan konteks yang lainya

- Wisdom merupakan knowledge yang telah diberikan insight sehingga wisdom mampu menunjukan hal apa yang sebaiknya dilakukan jika terjadi keadaan tertentu

- Decision merupakan wisdom yang sudah terarah pada suatu masalah / keadaan tertentu dengan tujuan untuk mengatasi masalah/keadaan tertentu .

- Wisdom dan Decision digunakan untuk mengatasi masalah yang akan muncul, apa langkah yang sebaiknya dilakukan, apa yang terbaik yang seharusnya dilakukan apabila terjadi suatu maslah / keadaan tertentu 
IoT merupakan system dengan skala besar yang heterogen dengan jumlah sumber daya (alat, koneksi, pemrosesan data) dan layanan yang besar. Oleh karena itu dibutuhkan manajemen sumber daya yang baik supaya IoT dapat memenuhi kebutuhan pengguna[4]. Secara garis besar, ada beberapa sumber daya dan layanan IoT yang perlu diperhatikan dalam pengambilan keputusan dengan IoT, antara lain:

- Data hasil Sensing : data dikumpulkan dari alat/sensor(physical layer). Data kemudian diolah menjadi informasi dan seterusnya sehingga akhirnya akan menjadi sebuah keputusan.

- Energi : Komponen IoT seperti sensor, server dan akses poin membutuhkan energy untuk melakukan tugas dan operasinya. Penyedia energi masih sedikit sehingga dapat mengatur dan memaksimalkan harga dari energy yang dibutuhkan komponen IoT[5]. Saat ini energi alternative yang recycle merupakan solusi yang tepat untuk meneyediakan energi bagi komponen IoT[6].

- Layanan Cloud : layanan cloud dapat berupa layanan penyimpanan data dan layanan komputasi yang tersedia dan dapat digunakan oleh pengguna IoT[7]. Banyak sekali layanan cloud yang menyediakan analisis pengambilan keputusan dari data hasil sensor IoT.

- Layanan data dan informasi: layanan data dan informasi dapat disajikan dan digabungkan untuk membantu aplikasi IoT dalam menyediakan layanan kepada pengguna IoT seperti pencarian informasi, data mining [8], dan keamanan data.

- Layanan berdasarkan lokasi : dengan menggunakan data gegrafis real-time dari alat seperti smartphones dan tablets, IoT menyediakan layanan berdasarkan lokasi yang dapat digunakan individu, organisasi bahkan pemerintah. Layanan ini dapat berupa layanan seperti mengidentifikasi keberdaan seseorang, tempat dan suatu acara, mengetahui tempat terdekat dari pengguna seperti SPBU, tempat makan dan toko[9]. Layanan berdasarkan lokasi merupakan layanan yang paling sering digunakan pengguna untuk membantu suatu pengambilan keputusan seperti tempat favorit, jalan yang harus dilewati dan lokasi macet.

\section{MODEL, TEKNOLOGI DAN TREN DALAM DECISION MAKING DENGAN IOT}

Pada bab ini akan dijelaskan beberapa model, teknologi dan tren dalam pengambilan keputusan dengan IoT. Seiiring dengan perkembangan penggunaan IoT, beberapa model, teknologi dan Tren penggunaan IoT telah diusulkan oleh peneliti sebelumnya. Dalam makalah ini model, teknologi dan Tren pengambilan keputusan dengan IoT merupakan rangkuman beberapa makalah(jounal dan konferensi).

\section{A. Model}

Dalam malakukan pengambilan keputusan dengan IoT, beberapa model digunkanan untuk meningkatkan performa dalam memilih keputusan secara cepat dan tepat. Dalam makalah ini akan dibahas 4 model yang digunakan dalam pengambilan keputusan dengan IoT antara lain : teori game, markovian decision process, Optimal Stoping problem, dan Multi-arm bandit problem.

- Teori Game

Teori game adalah suatu model matematika untuk menganalisa interaksi timbal balik dalam system pengambilan keputusan yang melibatkan dua atau lebih pengguna[10]. Model ini terdiri dari jumlah pemain, perintah, dan fungsi-fungsi yang tetap yang memetakan perilaku pemain kedalam suatu nilai tertentu. Secara garis besar, Teori game model dibagi menjadi 2 yaitu : cooperative game dan non-cooperative game.

Dalam model cooperative game, pemain berusaha membuat suatu keputusan yang tepat untuk memaksimalkan fungsi dan utilitas. Pada dasarnya, pemain(objek) dikelompokan dalam satu grup dan bekerjasama sesuai dengan porsi yang telah disepakati bersama.

Pada model non-cooperative game konsep solusi Nash Equilibrium (NE) dan correlated equilibrium $(C E)$ ditetapkan terlebih dahulu. Oleh karena itu, keputusan yang diambil pemain akan berbeda dan bisa secara otomatis yang akhirnya akan menimbulkan optimalisasi pada tiap-tiap keputusan yang diambil. 
NE merupakan solusi terbaik untuk non-cooperative game model dimana setiap pemain memaksimalkan fungsi utilitas pada setiap individu dengan memisahkannya secara sepihak. $\mathrm{CE}$ juga menyediakan solusi yang tepat untuk kejasama yang lebih baik dan desain fungsi utilitas yang fleksibel dengan menunjukan korelasi dari beberapa objek berdasarkan obsevasi. Beberapa game model yang cocok digunakan untuk pengambilan keputusan dengan IoT antara lain : Repeated game, Graphical game, evolutionary game,coalition game, hierarchical game dan Bayesian game.

- Markovian Decision Process(MDP)

MDP menyediakan framewaork yang tepat untuk memodelkan pengambilan keputusan dengan IoT pada beberapa objek dengan periode waktu yang beragam. Pada dasarnya, MDP menghitung kemungkinan suatu system akan berpindah dari keadaan tertentu ke keadaan lain berdasarkan maximum discounted reward untuk penghitungan kebijakan yang optimal. Peluang dari otcome tidak bergantung pada keadaan sebelumnya.

MDP menyediakan suatu lingkungan untuk penguatan pembelajaran dimana lingkunga tersebut dapat diamati secara detail dan menyeluruh. Masalah dengan pengambilan keputusan terurut dengan IoT dapat diselesaikan dengan baik menggunakan model MDP.

Fitur yang paling menarik dari teknik pemodelan ini adalah formulasi dari spectrum sensing dan pemilihan chanel yang menjadi salah sati masalah model MDP. Terdapat 3 tipe model dasar dari MDP yaitu : dicrete time MDP (DTMDP), partially observable MDP (POMDP) dan constrained $\mathrm{MDP}[11]$ yang menjadi enabler dalam pengambilan keputusan dengan IOT

- Optimal Stoping Problem(OSP)

OSP model menyelesaikan masalah pemilihan tindakan secara berurutan yang berdasarkan sebuah urutan dari variable random untuk memaksimalkan hasil yang diinginkan dan menurunkan biaya yang diperlukan. Proses ini melihat setiap variable berdasarkan hasil dan melakukan penghentian tindakan untuk mengurangi biaya yang diperlukan.

OSP model memiliki urutuan 1. Variable random $\mathrm{X} 1, \mathrm{X} 2, \ldots \ldots, \mathrm{Xn}$ yang memiliki distribusi bersama dan diketahui dan realisasinya yang di tulis dengan $\mathrm{x} 1, \mathrm{x} 2, \ldots, \mathrm{xn}$. 2. Fungsi pemetaan akan membuat random variable yang diamati dipetakan dengan hasil aslinya. Teknik ini dapat diimplementasikan menggunakan 2 model yaitu Non Recall-OSP dan Recall OSP.

- Multi-arm Bandit Problem

Multi-arm bandit (MAB) problem memberikan teknik pembelajaran terbaik untuk pemulihan satu atau lebih objek dari beberapa objek yang tidak diketahui informasi statistiknya. Pada dasarnya MAB memeriksa ukuran statistic tentang resources selama proses pemilihan keputusan dan memaksimalkan hasil yang dicapai saat ini berdasarkan estimasi ukuran statistic yang ada saat itu juga. Tujuan utama MAB adalah memodelkan aturan pembelajaran berdasarkan informasi keptusuan yang telah diambil sebelumnya untuk memaksimalkan jumlah hasil yang ingin dicapai.

MAB banyak dipelajari pada berbagai literature dan MAB dapat dikategorikan menjadi 2 yaitu rested $\mathrm{MAB}$ dan restless $\mathrm{MAB}$.

Dalam model rested MAB, state of arm hanya melakukan aksi/tugas saat dijalankan saja, pada kondis lain hanya akam diam dan menunggu perintah. Sedangkan pada model restless MAB state of arm selalu melakukan komputasi dan independent terhadap aksi yang sedang dijalankan. Pada model rested MAB ukuran yang digunakan adalah indeks Gittin's tertinggi, sedangkan restless MAB menggunakan indeks Whittle's tertinggi[12].

Keempat model pengambilan keputusan diatas memiliki kelebihan dan kekurangan masing - masing. Beberapa model cocok untuk satu kasus dan tidak pada kasus yang lain. Untuk itu diperlukan pemahaman lebih lanjut mengenai penggunaan model yang akan dipakai berdasarkan karakteristik setiap model pengambilan keputusan yang akan digukanann

Tabel 2 menggambarkan komparasi dari 4 model berdasarkan tujuan, pengambilan informasi dan biaya yang harus dipertimbangkanb dalam menggunakan model. 
Tabel 2. Perbandingan model Decision Making dengan IoT

\begin{tabular}{|l|l|l|l|}
\hline & \multicolumn{1}{|c|}{ Tujuan } & \multicolumn{1}{c|}{ Information retrieval } & \multicolumn{1}{c|}{ cost } \\
\hline Game Model & $\begin{array}{l}\text { Interaksi antara beberapa } \\
\text { objek untuk pemilihan objek } \\
\text { yang efektif }\end{array}$ & $\begin{array}{l}\text { Perilaku dari suatu objek } \\
\text { berpengaruh langsung } \\
\text { terhadap perilaku onjek lain }\end{array}$ & $\begin{array}{l}\text { Sumber daya digunakan } \\
\text { untuk pertukaran } \\
\text { informasi antar } \\
\text { pengguna. } \\
\text { Memperhatikan biaya } \\
\text { peralihan(switching cost) } \\
\text { sebelum solusi } \\
\text { ditemukan }\end{array}$ \\
\hline $\begin{array}{l}\text { Markovian } \\
\text { Procession }\end{array}$ & $\begin{array}{l}\text { Perumasan dalam spectrum } \\
\text { sensing dan pemilihan chanel }\end{array}$ & $\begin{array}{l}\text { Informasi tentang keadaan } \\
\text { system dinamis dan saling } \\
\text { berhubungan }\end{array}$ & $\begin{array}{l}\text { Hanya memperhatikan } \\
\text { biaya peralihan saat } \\
\text { proses pemilihan }\end{array}$ \\
\hline $\begin{array}{l}\text { Optimal } \\
\text { Stoping } \\
\text { Problem }\end{array}$ & $\begin{array}{l}\text { Menghitung trade off antara } \\
\text { biaya dari objek sensing dan } \\
\text { hasil yang ingin dicapai } \\
\text { berdasarkan biaya }\end{array}$ & $\begin{array}{l}\text { Uncertain realization terhadap } \\
\text { chanel yang belom ditelusuri }\end{array}$ & $\begin{array}{l}\text { Biaya peralihan ada. } \\
\text { Memperhatikan } \\
\text { beberapa variable yang } \\
\text { ada berdasarkan } \\
\text { performanya untuk } \\
\text { meminimalisir biaya }\end{array}$ \\
\hline $\begin{array}{l}\text { Multi-arm } \\
\text { Bandit Problem }\end{array}$ & $\begin{array}{l}\text { Teknik yang paling sesuai } \\
\text { berdasarkan informasi } \\
\text { statistik tentang lingkungan } \\
\text { untuk mempelihatkan trade } \\
\text { of antara exploitasi dan } \\
\text { eksplorasi }\end{array}$ & $\begin{array}{l}\text { Informasi statistic terhadap } \\
\text { objek dan lingkungan tidak } \\
\text { diketahui }\end{array}$ & $\begin{array}{l}\text { Biaya } \\
\text { pemilihan(selection cost) } \\
\text { dikelola dengan baik }\end{array}$ \\
\hline
\end{tabular}

\section{B. Teknologi}

- Radio Frequency Identification(RFID)

RFID system terdiri dari satu atau lebih reader dan beberapa RFID tag. RFID menggunakan medan elektromagnetik frekuensi radio untuk mengirimkan data yang diattach didalamnya. Tag yang ada pada RFID menyimpan data secara elektronik yang ekmudian dapat dibaca oleg reader.RFID memungkinkan pengguna melakukan monitoring secara real-time tanpa harus melihat secara langsung devices RFIDnya[13].

Ada tiga jenis konfirmasi RFID tag yaitu : Passive Reader Active tag(PRAT), Active Reader Passive Tag(ARPT) dan Active Reader Active Tag(ARAT). Dalam PRAT reader bersifat passive, hanya menerima sinyal dari RFID tag. PRAT biasanya memiliki range antara 1-2000 feet tergantung jenis arsitektur yang digunakan. Konfigurasi yang paling sering digunakan adalah ARPT dimana device tidak memiliki pasokan energy pada tagnya. Sehingga konsumsi 
energy yang digunakan untuk mengirim data didapatkan dari RFID reader. Konfigurasi terakhir adalah ARAT dimana reader dan tag active. Tag hanya active saat RFID reader mengirimkan sinyal/berada disekitar tag.

Pemanfaatan teknologi RFID sudah sangat umum pada kehidupan sehari-hari antara lain: smart card, access card dll. Data yang dihasilkan dikirmkan melalui network kemudian dianalisis lebih lanjut sehinga menghasilkan knowledge.

- Near Field Communication (NFC)

NFC memiliki konfigurasi yang sama dengan RFID. NFC dapat dibuat sesuai dengan keinginan pengguna dengan cara menggabungkan RFID reader ke sebuah mobile phone. Terdapat komunikasi radio antara NFC mobile device dengan menghubungkannya kedalam domain dari mobile phone yang lain.

Komunikasi dilakukan dalam jarak dekat, wireless link dengan konsusmsi daya rendah digunkana untuk mengirimkan data dalam jumlah kecil dengan jangkauan terbatas spesifik pada suatu domain. Tidak perlu dilakukan pairing sebelum device benar-benar melakukan pengiriman data berbeda dengan tenologi Bluetooth.

NFC beroperasi dalam unlicensed radio frequency band $13.56 \mathrm{MHz}$ dang rata-rata memiliki jangkauan sebesar 20 meter tergantung kualitas antenna yang digunkan. NFC diprediksi akan memerankan peran yang besar dalam pemanfaatan teknologi IoT. NFC akan menjadi enabler yang memberikan tools yang sesuai untuk menghubungkan beberapa smart object.

- Machine-to-Machine Comunication (M2M)

M2M merupakan bentuk dari komunikasi antara komputer, embedded processors, sensor pintar, actuators dan mobile device. Komunikasi antar mesin ini mulai berkembang dengan pesat dan menjadi perhatian seiring dikenalnya IoT. Ada 4 komponen dari M2M yaitu sensing, akses heterogen, pemrosesan informasi, dan aplikasi.

Secara garis besar, struktur M2M terdiri dari 5 bagian yaitu: M2M Device(alat yang dapat memberikan respon terhadap request data yang terdapat dalam alat tersebut), M2M Network( memebrikan konektivitas antara M2M device dengan M2M Gateway), M2M Gateway(memastikan M2M device terhubung dalam sebuah jaringan komunikasi), M2M communication Network(menghubungkan M2M gateway dengan M2M application), M2M application(merupakan layer dimana data diproses dalam beberapa servis yang digunkan dalam proses bisnis secara spesifik).

- Vehicle-to-Vehicle Communication(V2V)

Merupakan komunikasi yang menggunakan kendaran sebagai sebuah titik yang didalamnya terdapat berbagai jenis sensor dan alat komunikasi yang terhubung dalam suatu jaringan komunikasi. Kamunikasi jenis ini memiliki topologi jaringan yang berubah - ubah karena pada dasarnya kendaraan merupakan sebuah benda yang bergerak sehingga jaringan yang terbentuk dari koneksi beberapa kendaraan akan berubah - ubah sesuai dengan keberadaan kendaraan itu sendiri.

Kendaraan berkomunikasi satu sama lain biasanya memiliki jangkauan akses jaringan kurang dari 1000m. koneksi antar kendaraan bisa bersifat langsung antar kendaraan atau merupakan bagian dari sebuah infrastruktur yang lebih besar misalnya infrastruktur sebuah jaringan jalan.

Berdasarkan kegunaanya,V2V dapat dikategorikan menjadi 4 yaitu : jaringan keselamatan berkendara(collision avoidance), sistem manajemn jaringan lalu lintas, vehicle telematics, dan konektivitas internet\&system hiburan.

- Teknologi Komunikasi dalam IoT

IoT bisa saja terdiri dari beberapa alat elektronik, peralatan mobile, dan perlengkapan industry. Alat yang berbeda memiliki jenis komunikasi, jaringan, pemrosesan data, kapasitas penyimpanan dan sumber energi yang berbeda-beda. Semua komponen alat IoT dapat 
terkoneksi dengan teknologi komunikasi dan jaringan seperti WSN(Wireless Sensor Networks), WSAN(Wireless Sensor Actuator Networks), wireless mesh network dan wireless LAN.

Teknologi komunikasi dan jaringan diatas membantu Things dalam IoT bertukar informasi dan mengirimkan data ke proses pengolahan data. Sebuah gateway memiliki kemapuan untuk melakukan komunikasi dan interaksi antara beberapa alat melalui internet. Beberapa gateway juga memiliki kemampuan untuk melakukan pemrosesan data sederhana. Oleh kerena itu, gateway dapat digunkan untuk menangani aspek kompleks yang berkaitan dengan komunikasi dalam suatu jaringan[14].

\section{Tren}

Penggunaan IoT dalam berbagai bidang kehidupan sudah mengalami perkembangan yang sangat pesat. IoT digunakan oleh individu, perusahaan/organisasi, bahkan pemerintah dalam membantu memenuhi segala kebutuhan penggunanya. IoT digunakan dalam rumah, pabrik, kantor, hutan, sungai bahkan laut. Semua bidang menggunakan IoT sebagai alat bantu untuk mengambil keputusan keputusan strategis.

Beberapa bisnis/ aspek kehidupan yang menggunakan IoT untuk melakukan pengambilan keputusan anatara lain industry manufaktur, industry makanan, konstruksi, transportasi dan lingkungan.

- Manufaktur

Industri manufaktur merupakan salah satu bidang insutri yang menggunakan IoT dalam melakukan pengambilan keputusan. Kaur dan Soot[15] mengajukan sebuah pendekatan system IoT menggunakan teori game untuk melakukan penilaian pada pegawai. Data yang digunakan berasal dari sensor kegiatan pabrik (data lingkungan, material tracking, monitoring air, monitoring listrik dan beberapa data sensor lainya) dan data pribadi pegawai (kesehatan dan data lokasi). Kaur dkk menggunakan teori game dalam melakukan pengambilan keputusan berdasarkan data yang dikumpulkan dan memberi performa yang lebih bagus disbanding dengan model pengambilan keputusan yang lain.

Brundage dkk[16] mengajukan EP-BN(Enegy profit bottleneck) untuk memonitor dan mengontrol konsumsi energi selama proses manufaktur. Skema EP-BN membantu perusahaan mengambil keputusan dalam pengalokasian anggaran dan efisiensi penggunaan energi yang digunkan perusahaan.

- Industri makanan

Dalam industry makanan IoT digunakan untuk melakukan QC(quality control) yaitu dengan memantau kualitas dari produk makanan yang dihasilkan[17]. Pengawasan dilakukan dengan memasang beberapa sensor pada saat proses pemilihan bahan mentah, pembuatan produk makanan, pengemasan makanan dan proses pengiriman makanan.

- Pertambangan

Dalam pertambangan IoT digunakan dalam beberapa aspek seperti deteksi kebocoran penampungan limbah dalam manajemen pengolahan limbah tambang[18] dan proses keselamatan dalam proses penggalian tambang[19].

Dalam proses manajemen pengolahan limbah tambang IoT digunakan untuk mendeteksi kegagalan system penampungan limbah tambang yang dapat menyebabkan kebocoran dan rusaknya penampungan limbah tambang. Sun dkk[18] mengusulkan TDMPAS(tailing dam monitoring and pre-alarm system) untuk mengamati level air, garis jenuh dan perubahan bentuk dari penampungan limbah. Model membuat rekomendasi tentang kemanan dari penampungan limbah dan membuat peringatan dini sehingga membatu manajemen mengambil keputusan tentang perbaikan dan perawata penampungan limbah hasil tambang.

Untuk keselamatan dalam proses penggalian tambang, IoT digunakan untuk mengetahui peringatan dari kecelakaan proses penambangan untuk membuat peringatan dini, prediksi kecelakaan/bencana dan peningkatan keselamatan dalam proses penambangan bawah tanah. Dengan menggunakan RFID, WiFi dan teknologi komunikasi wireless lainya serta alat yang 
efektif untuk melakukan komunikasi antara bawah tanah dan kantor, perusahaan tambang dapat mengetahui posisi penambang yang berada dibawah tanah dan menyiapkan prosedur keaman apabila terjadi kecelakaan atau bencana.

- Transportasi dan logistik

IoT memainkan peran yang sangat penting dalam bidang transportasi dan logistik. Dengan semakin banyaknya objek(benda, kendaraan) yang memiliki sensor atau RFID tags, perusahaan transportasi dan logistik dapat memantau secara real-time pergerakan dari objek dari tempat asal menuju tujuan melewati berapa distributor mulai dari produksi, pengiriman sampai distribusinya[20]. Selanjutnya, IoT diharapkan akan memberikan solusi dari berbagai permasalahan transportasi yang ada seperti kemacetan dan kecelakaan[21], [22]. IoT juga diharapkan memberi solusi dalam hal pengembangan mobil pintar.

Saat ini, system pintar untuk berkendara(iDrive system) dikembangkan BMW menggunakan berbagai sensor dan tag untuk memantau keadaan lingkungan seperti mendeteksi keberadaan kendaraan dan kondisi jalan untuk memberikan panduan berkendara yang tepat bagi pengguna[23]. Berbagai algoritma digunakan untuk melakukan komunikasi dan pertukaran data dan informasi antar kendaraan.

- Lingkungan

Pada bidang lingkungan hidup, penggunaan IoT juga mengalami kemajuan yang pesat. IoT digunakan untuk berbagai kegunaan antara lain efisiensi konsumsi air[24] dan penanggulangan bencana kebakaran[25]. Dengan IoT diharapkan maslaah lingkunga hidup dapat diatasai dengan cepat dan tepat.

Efisiensi konsumsi air merupakan masalah yang penting saat ini seiring dengan peningkatan permintaan air dan berkurangnya sumber mata air bersih yang ada. Data dikumpulkan dari sensor yang dipasang pada mata air, sungai oleh perusahaan dan pemerintah. Data selanjutnya diproses sehingga menghasilkan keputusan yang tepat dalam peningkatan efisiensi pemakain air. Keputusan akan membuat pasokan air stabil, konsumsi efekstif dan mendeteksi apabila ada kebocoran air.

IoT mulai digunakan dalam keselamatan proses pemadaman kebakaran untuk mendeteksi sumber api dan memberikan peringata dini apabila kebakaran terjadi. Di China, RFID tag dan barcode diapasang pada alat pemadam kebakaran untuk mengumbulkan data dan informasi tentang kebakaran. Dengan menggunakan RFID tag, reader,kamera video dan sensor api, pemadam kebakaran dapat mengetahui keadaan lingkungan saat terjadi kebakaran dan memberikan prosedur penyelamatan yang tepat bagi korban kebakaran.

- Kesehatan

IoT menyediakan penawaran/kesempata baru untuk meningkatkan pelayan pada bidang kesehata bidang kesehatan[26]. Dengan kemampuan IoT yang bisa mengidektifikasi, sensing dan kemampuan komunikasi, semua objek dalam system kesehata(manusia, peralatan medis dan obat) dapat dilacak dan dipantau secara periodik. Dengan berkembangnya teknologi informasi, informasi terkait bidang kesehatan(logistic, diagnose, terapi, proses penyembuhan, pengobatan, manajemen dan diagnose) dapat dikumpulkan, dikelola, dan disebarluaskan secara lebih efisien. Sebagai contoh, kondisi kesehatan pasien(detak jantung, tekanan darah) dapat diukur dengan jam tangan pintar dan dapat langsung dikirimkan ke dokter yang bertanggung jawab atas pasien tersebut. Dengan menggunakan smart device (smartphones, smart watch, smart ring dsb) dan akses internet, layanan IoT dalam bidang kesehatan dapat diakses secara leluasa dan sesuai dengan kebutuhan pasien. 
Tabel 2. Perkembangan pemanfaatan IoT dalam berbagai aspek kehidupan

\begin{tabular}{|c|c|c|c|}
\hline Bisnis & Analisis & teknologi & Outcome \\
\hline $\begin{array}{l}\text { Manufaktur [15], } \\
{[16]}\end{array}$ & $\begin{array}{l}\text { - Otomatisasi penilaian } \\
\text { performa pegawai } \\
\text { - Meningkatkan keuntungan, } \\
\text { mengurangi biaya dan } \\
\text { mempercepat proses } \\
\text { produksi }\end{array}$ & $\begin{array}{l}\text { - RFID dan game } \\
\text { model } \\
\text { - EP-BN }\end{array}$ & $\begin{array}{l}\text { - Meningkatkan kinerja } \\
\text { pegawai } \\
\text { - Mengurangi biaya energy } \\
\text { - Menaikan keuntungan }\end{array}$ \\
\hline $\begin{array}{l}\text { Industry } \\
\text { makanan[17] }\end{array}$ & $\begin{array}{l}\text { - Pengawasan kualitas(QC) } \\
\text { dari produk makanan }\end{array}$ & $\begin{array}{l}\text { - Ontology based } \\
\text { context modelling }\end{array}$ & $\begin{array}{l}\text { - Meningkatkan kualitas } \\
\text { produk }\end{array}$ \\
\hline $\begin{array}{l}\text { Pertambangan[18] } \\
{[19]}\end{array}$ & $\begin{array}{l}\text { - Membangun bendungan } \\
\text { dengan aman } \\
\text { - Mengamati perubahan } \\
\text { bentuk bendungan dan } \\
\text { ketinggian air } \\
\text { - Mengetahui posisi } \\
\text { penambang yang berada } \\
\text { pada bawah tanah } \\
\text { - Mempersiapkan prosedur } \\
\text { keamanan terbaik }\end{array}$ & $\begin{array}{l}- \text { Presure sensor } \\
- \text { Water level sensor } \\
\text { - Deformation sensor } \\
\text { - Cloud computing } \\
- \text { RFID } \\
\text { - WiFi }\end{array}$ & $\begin{array}{l}\text { - Keamanan bendunga } \\
\text { - Pre-alarm information } \\
\text { - Prediksi kecelakaan } \\
\text { - Prosedur keamanan terbaik }\end{array}$ \\
\hline $\begin{array}{l}\text { Transportasi[22] } \\
{[27]}\end{array}$ & $\begin{array}{l}\text { - Optimalisasi sumber daya } \\
\text { - Pertukaran informasi antar } \\
\text { kendaraan } \\
\text { - Memonitor keberadaan bus } \\
\text { melalui aplikasi mobile } \\
\text { - Mobil otomatis }\end{array}$ & $\begin{array}{l}\text { - Fuzzy Decision } \\
\text { Making dan aplikasi } \\
\text { android } \\
\text { - V2V } \\
\text { - IoT tracking unit } \\
\text { - QGIS }\end{array}$ & $\begin{array}{l}\text { - Meingkatkan kecepatan } \\
\text { pertukaran informasi antar } \\
\text { kendaraan } \\
\text { - Kenyamanan transportasi } \\
\text { - Pembuatan mobil otomatis }\end{array}$ \\
\hline Lingkungan[24][25] & $\begin{array}{l}\text { - Mengelola Penggunaan Air } \\
\text { - Pemenuhan kebutuhan air } \\
\text { - Peringatan dini kebakaran } \\
\text { - Perencanaan prosedur } \\
\text { pemadaman dan } \\
\text { penyelamatan korban }\end{array}$ & $\begin{array}{l}\text { - Big Data } \\
- \text { IoT Sensor } \\
- \text { WSN } \\
\text { - RFID } \\
\text { - Kamera video }\end{array}$ & $\begin{array}{l}\text { - Optimalisasi pasokan air } \\
\text { dan penggunaanya } \\
\text { - Deteksi kebocoran } \\
\text { - Deteksi titik api } \\
\text { - Deteksi jalur evakuasi } \\
\text { - Penyelamatan korban } \\
\text { kebakaran }\end{array}$ \\
\hline
\end{tabular}




\begin{tabular}{|l|l|l|l|}
\hline & & & \\
\hline Kesehatan [26] & - Pemanfaatan smart device & - Smart watch & - Peningkatan kualitas \\
& untuk memonitor kesehatan & pelayan kesehatan \\
& pasien & - IoT sensor & - Deteksi dini gangguan \\
& - Mengirimkan data kesehatan & & kesehatan \\
& ke dokter secara peiodik & & \\
\hline
\end{tabular}

\section{CONCLUSION}

IoT diharapkan memberikan peluang yang besar untuk prosesn pengambilan keputusan dengam memberikan data dan analisis yang baik akan masalah yang sedang dihadapi pengguna. Arstitektur IoT memacu berbagai kemungkinan pemanfaatan IoT lebih lanjut dalam hal pengambilan keputusan. Framework pengambilan keputusan memberi gambaran bagaimana sebuah data berubah menjadi keputusan melalui berbagi tahap dengan menambah berbagai komponen. Beberapa model, teknologi dan tren yang ada saat ini dalam pengambilan keputusan dapt menjadi masukan dalam menyelesaikan sebuah masalah.

\section{REFERENSI}

[1] L. Mann, R. Harmoni, C. Power, G. Beswick, and C. Ormond, "Effectiveness of the GOFER course in decision making for high school students," J. Behav. Decis. Mak., vol. 1, pp. 159$168,1988$.

[2] K. L Guo, "DECIDE: A decision-making model for more effective decision making by health care managers," Health Care Manag. (Frederick)., vol. 27, pp. 118-127, 2008.

[3] F. Carrez, "Designing IoT Architecture ( s ) A European Perspective," pp. 79-84, 2014.

[4] J. Xu, S. Member, and Y. Andrepoulos, "Non-Stationary Resource Allocation Policies for Delay-Constrained Video Streaming: Application to Video over Internet-of-Things-Enabled Networks," vol. 32, no. 4, pp. 782-794, 2014.

[5] Y. Feng, B. Li, S. Member, and B. Li, "Price Competition in an Oligopoly Market with Multiple IaaS Cloud Providers," vol. 63, no. 1, pp. 59-73, 2014.

[6] S. P. Beeby, M. J. Tudor, and N. M. White, "Energy harvesting vibration sources for microsystems applications," vol. 17, 2006.

[7] R. Buyya, C. S. Yeo, S. Venugopal, and S. Engineering, "Market-Oriented Cloud Computing: Vision, Hype, and Reality for Delivering IT Services as Computing Utilities," 1969.

[8] S. Bin, L. Yuan, and W. Xiaoyi, "Research on Data Mining Models for the Internet of Things," 2010.

[9] Z. Chen, F. Xia, T. Huang, F. Bu, and H. Wang, "A Localization Method for the Internet of Things."

[10] R. Trestian, O. Ormond, and G. Muntean, "Game Theory-Based Network Selection : Solutions and Challenges," IEEE Commun. Surv. Tutorials, vol. 14, no. 4, pp. 1212-1231, 2012.

[11] Y. Xu, S. Member, A. Anpalagan, S. Member, Q. Wu, and S. Member, "Decision-Theoretic Distributed Channel Selection for Opportunistic Spectrum Access : Strategies, Challenges and Solutions," IEEE Commun. Surv. Tutorials, vol. 15, no. 4, pp. 1689-1713, 2013.

[12] C. Tekin and M. Liu, "Online Learning of Rested and Restless Bandits," pp. 1-33.

[13] L. Battle et al., "Building the Internet of Things Using RFID: The RFID Ecosystem Experience," IEEE Internet Comput., vol. 13, no. 3, pp. 48-55, 2009.

[14] Q. Zhu, R. Wang, Q. Chen, Y. Liu, and W. Qin, "Bridging Wireless Sensor Networks into Internet of Things," 2010 IEEE/IFIP Int. Conf. Embed. Ubiquitous Comput., pp. 347-352, 2010.

[15] N. Kaur and S. K. Sood, "A Game Theoretic Approach for an IoT-Based Automated Employee Performance Evaluation," vol. 11, no. 3, pp. 1385-1394, 2017. 
[16] M. P. Brundage, S. Member, Q. Chang, Y. Li, J. Arinez, and G. Xiao, "Implementing a RealTime , Energy-Efficient Control Methodology to Maximize Manufacturing Profits," IEEE Trans. Syst. Man, Cybern. Syst., vol. 46, no. 6, pp. 855-866, 2016.

[17] B. Jia, "The Design of Food Quality Supervision Platform Based on the Internet of Things," Proc. 2011 Int. Conf. Transp. Mech. Electr. Eng., pp. 263-266, 2011.

[18] E. Sun and X. Zhang, "The Tailings Dam Monitoring and Pre-Alarm System (TDMPAS) and its applications in mines," 2012 SME Annu. Meet. Exhib. 2012, SME 2012, Meet. Prepr., pp. 232-236, 2012.

[19] W. E. I. Qiuping, Z. H. U. Shunbing, and D. U. Chunquan, "Procedia Engineering Study on key technologies of Internet of Things perceiving mine," Procedia Eng., vol. 26, pp. 23262333, 2011.

[20] B. Karakostas, "A DNS Architecture for the Internet of Things: A Case Study in Transport Logistics," Procedia - Procedia Comput. Sci., vol. 19, no. Ant, pp. 594-601, 2013.

[21] H. Zhou, B. Liu, and D. Wang, "Design and Research of Urban Intelligent Transportation System Based on the Internet of Things," no. 70031010, pp. 572-573, 2012.

[22] G. Cueva-fernandez, J. Pascual, and V. García-díaz, "Fuzzy decision method to improve the information exchange in a vehicle sensor tracking system," Appl. Soft Comput. J., pp. 1-9, 2015.

[23] E. Qin, Y. Long, C. Zhang, and L. Huang, "Cloud Computing and the Internet of Things : Technology Innovation in Automobile Service," pp. 173-174, 2013.

[24] D. Koo, K. Piratla, and J. M. C, "Towards Sustainable Water Supply: Schematic Development of Big Data Collection Using Internet of Things ( IoT )," vol. 118, pp. 489-497, 2015.

[25] Z. Ying-cong and Y. U. Jing, "A Study on the Fire IOT Development Strategy," Procedia Eng., vol. 52, pp. 314-319, 2013.

[26] M. Carmen, "An overview of the Internet of Things for people with disabilities," J. Netw. Comput. Appl., vol. 35, no. 2, pp. 584-596, 2012.

[27] M. Al-jabi, "Toward an IoT-Enabled Adaptive Interactive Bus Transportation system," pp. 69, 2017. 